\title{
The Influence of The Protein Source in Clinical Outcomes of Patients on Enteral Nutrition Therapy
}

\author{
Suellen Guesser Homem ${ }^{1}$ and Maria Eliana Madalozzo Schieferdecker ${ }^{2 *}$ \\ ${ }^{1}$ Multiprofessional Residency Program in Adult and Elderly Healthcare, Clinics Hospital Complex, Federal University of Paraná, Curitiba, \\ PR, Brazil. \\ ${ }^{2}$ Department of Nutrition, Postgraduate Program on Food and Nutrition, Federal University of Paraná, Curitiba, PR, Brazil.
}

*Corresponding author: Maria Eliana Madalozzo Schieferdecker, Postgraduate Program on Food and Nutrition of the Department of Nutrition, Federal University of Paraná - UFPR. Adress: 632 Lothario Meissner Avenue, Curitiba, Paraná, Brazil.

\begin{abstract}
The nutritional therapy aims to maintain or recover the nutritional status, and the enteral nutrition therapy is used when oral feeding is not indicated or when the individual's nutritional needs are not met. During hospitalization, nutritional status impairment may be fast, and malnutrition increases the risk of complications and mortality. Enteral formulas can be composed of plant or animal proteins, but it is not clear whether different sources influence in clinical outcomes. Considering the lack of studies addressing this topic, evidence related to the type of protein source in enteral nutritional therapy was compiled in order to identify differences in clinical outcomes of patients using nutritional therapy. Studies that were included in the review show that the use of enteral formulas based on vegetable protein appear to be as efficient as animal protein based formulas, regarding maintenance of nutritional status, improvement of glycemic control and minimizing gastrointestinal complications when compared to animal protein. The limited number of studies and differences in study design and characteristics make it difficult to draw evidence-based conclusions. Thus, further studies are needed to elucidate the role of vegetable protein in clinical outcomes when compared to animal protein.
\end{abstract}

Abbreviations: Nutritional Therapy; Enteral Nutrition; Vegetable Protein; Soy Protein; Nutritional Status

\section{Introduction}

Nutritional therapy is understood as the supply of nutrients to maintain or recover the nutritional status, and that can be performed through oral, enteral and parenteral routes [1]. The enteral nutrition therapy (ENT) is characterized by a set of therapeutic procedures for nutrient supply using the gastrointestinal tract when oral intake is insufficient or contraindicated [2,3]. In choosing the nutritional route, the enteral nutrition (EN) should be the first option when oral route is not possible [3]. The enteral route provides beneficial effect on intestinal barrier function, increasing the mucus, bile and immunoglobulins secretion [4]. During hospitalization, in the hospital or at home, nutritional status can often be neglected. Malnourished patients are at higher risk for infections, pressure injuries and other clinical complications, which may increase length of hospital stay, worsen quality of life, and increase mortality rates [2,5]. Providing adequate nutritional support can have a positive effect on mortality and improve patients' quality of life [6]. In hospitalized patients the nutritional therapy is more complex because of their instability in the acute phase of the disease, requiring the monitoring of metabolic response and the determination of caloric, protein and micronutrient needs [7]. Depending on the severity of the disease, one of the main consequences of metabolic stress is the resistance to anabolic signs, which leads to protein loss. Since the rate of protein degradation is higher than its synthesis, the result is a negative muscle protein balance [8].

The nutrients that compose the enteral formulas can be obtained from several food sources. Proteins can be from animal sources (milk protein, casein) or vegetable sources (soy, rice, pea). The energy-protein necessity of patients should be met regardless the source of the nutrients of the formula. Studies show that there is no 
difference between plant or animal protein absorption in the body, and vegetable protein is enough to provide the necessary amino acids for metabolic processes $[9,10]$. However, studies evaluating the difference between protein sources in enteral formulas are still scarce. Several dietary supplements of plant-based protein have appeared, aimed mainly at the sports public, and studies show good results when they relate their use to physical exercise and sports performance compared to animal protein supplements. However, these products are designed to complement the diet in terms of proteins and amino acids, not meeting the need for a complete enteral nutrition formula that is composed of all macronutrients and macronutrients in the recommended intake amounts[11,12]. There are few formulas with a purely vegetable protein source available on the market. Currently commercialized enteral formulas are composed of casein, whey protein or mixtures of these with soy protein. On the other hand, the number of patients with food intolerance or allergies who need specific formulas has increased. Another fact to be considered is the cultural aspects and beliefs, in which individuals choose not to use animal protein sources. Strict vegetarians are a good example [13] because of issues related to health, ethics and animal rights, environment, economy and religion $[14,15]$ they choose for the absolute restriction of animal sources. Therefore, this study aims to promote a better understanding about EN with plant protein sources and to provide greater security for health professionals when prescribing ENT, so as to respect the bioethics principles of autonomy, nonmaleficence, beneficence and justice[16].Thus, this study aims to identify in the literature whether there are differences in clinical outcomes of individuals undergoing enteral nutrition therapy with different protein sources.

\section{Methods}

This study is an integrative review developed according to the following steps:

$1^{\text {st }}$ Elaboration of a guiding question - A review was developed to answer the following question: "Is there any difference between the use of formulas with vegetable protein source and animal protein source in clinical outcomes of adult and elderly patients on enteral nutrition therapy?; 2nd Definition of search terms - The search was performed using combinations of terms to identify original studies that evaluated outcomes according to the protein source of enteral formulas. The descriptors used in the search were: "enteral nutrition", "food, formulated", "vegetable proteins" and "soybean protein". The search terms were combined using Boolean operators (OR to match the same group search terms and AND to match search terms from different groups) and quotation markers were used to search for exact terms or expressions and parentheses to indicate a group of search terms or to combine two groups of search terms, allowing all possible sentence combinations. The search description was as follows: ("Enteral Nutrition" OR "Food, Formulated") AND ("Vegetable Proteins" OR "Soybean Proteins"). $3^{\text {rd }}$ Inclusion and Exclusion Criteria - The inclusion criteria were: original articles, preferably clinical trials comparing vegetable and animal protein sources, studies with adults and/or elderly. Thus, the exclusion criteria were non-original and review articles, in vitro studies, animal model studies, studies with children and studies in languages other than English, Portuguese, and Spanish. The bibliographic research was conducted from May to October 2019.

$4^{\text {th }}$ Database search - The bibliographic search was performed in PubMed / MEDLINE, The Cochrane Central Register of Controlled Trials (CENTRAL), Scopus, LILACS, Sci ELO and Clinical Trials databases, besides the gray literature such as Open Gray and ISRCTN Registry to identify all studies published so far, in the languages required and without date filter. After the search, duplicate articles were excluded, and the titles' articles were read. Subsequently, the abstracts of the found studies were read in order to refine the articles only potentially relevant to the study, disregarding all those that were not related to the theme and did not meet the inclusion criteria. All studies that met the inclusion criteria were reviewed. After the complete reading of the studies, they were analyzed according to the established criteria. The flowchart of the selection and eligibility process of the articles is shown in Figure 1.

\section{Results}

Comparison between the use of animal protein and vegetable protein in enteral formulas from the 241 studies identified, only four studies published between 1990 and 2018 could be analyzed. The four studies covered 202 patients and assessed the difference in clinical outcomes of patients using enteral nutrition with vegetable or animal protein sources (Table 1). The studies were conducted in Spain17, The United States18, China19 and a multicenter study covering 5 sites (2 in The United Kingdom, 1 in Israel and 2 in Brazil)20. Participants were older than 50 years, paired between groups according to the formula offered, as well as their gender. Sample sizes ranged from 23 to 104 participants. All studies corresponded to intervention clinical trials, comparing the group using animal protein source formula (casein) with the group using vegetable protein source formula (soy). The duration of the studies ranged from 65 days to 12 months and the intervention time ranged from 6 to 42 days. From the 202 patients, 100 received the intervention formula with vegetable protein source. The patients' diagnoses and outcomes varied among studies. Two studies have evaluated glycemic control in patients with different exposures, including post stroke patients17 and diabetic patients18. GarcíaTalavera Espín et al. [17] evaluated prevalence, classification and degree of malnutrition, gastrointestinal effects (diarrhea, constipation and vomiting), complications (pressure injury and fever) and mortality in hospitalized patients and Viall et al. [18] evaluated only gastrointestinal complications in non-surgical hospitalized patients with various diagnoses, mainly stroke and cancer, all on enteral nutrition therapy. 


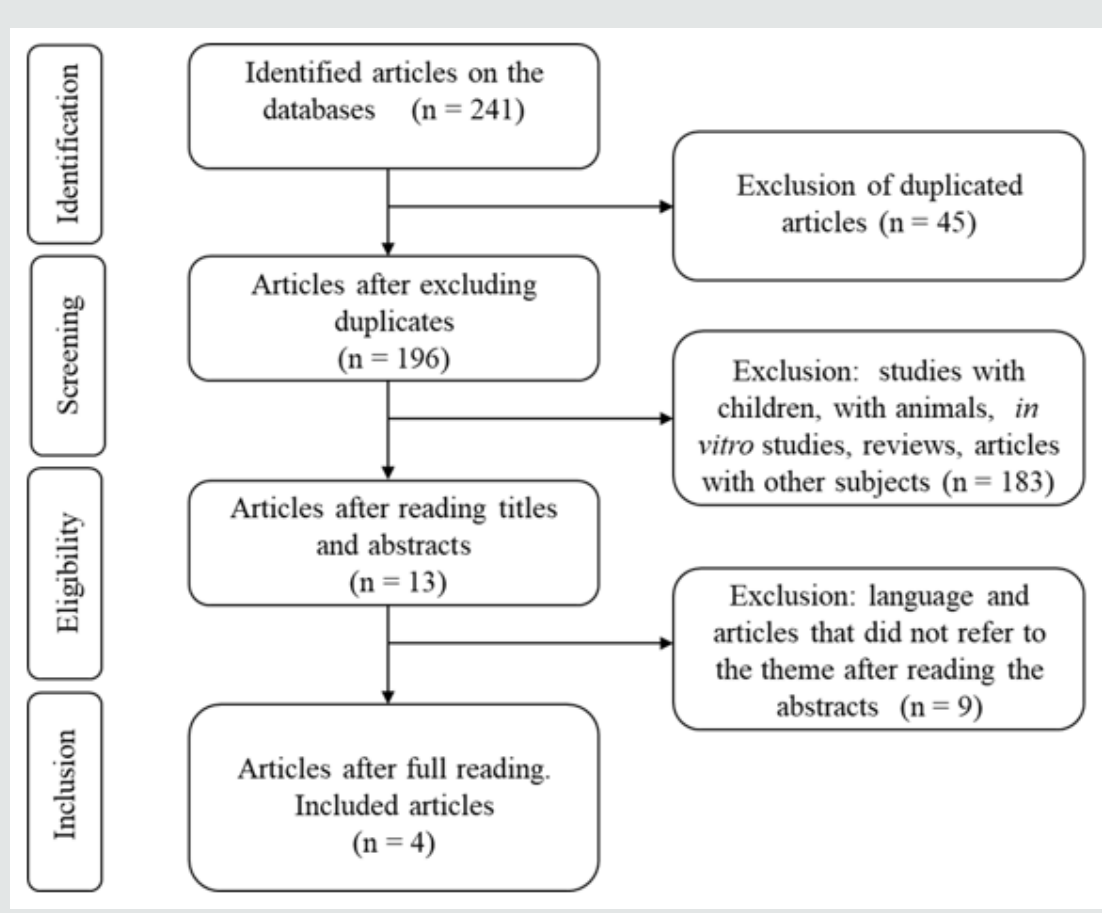

Figure 1: Flowchart of the selection process of articles that evaluated the difference between protein sources of enteral formulas.

Table 1: Studies that analyzed clinical outcomes in patients on enteral nutrition therapy (ENT) with animal and vegetable protein sources.

\begin{tabular}{|c|c|c|c|c|c|c|}
\hline Author & Population/sample & ENT & Study design & $\begin{array}{l}\text { Length of the } \\
\text { study }\end{array}$ & Outcome & Main results \\
\hline Viall et al. [18] & $\begin{array}{l}\text { Hospitalized non- } \\
\text { surgical patients } \\
\text { (n=23; intervention } \\
\text { group = 11, control } \\
\text { group = 12) }\end{array}$ & $\begin{array}{l}\text { Yes (JTM out } \\
\text { NGT) }\end{array}$ & $\begin{array}{l}\text { Intervention: } \\
\text { soy protein diet } \\
\text { compared to a } \\
\text { casein-based } \\
\text { control formula }\end{array}$ & 65 days & $\begin{array}{l}\text { Gastrointestinal side } \\
\text { effects (diarrhea, gastric } \\
\text { residue, vomiting) }\end{array}$ & $\begin{array}{l}\text { Better gastric emptying } \\
\text { and lower incidence of } \\
\text { vomiting and diarrhea }\end{array}$ \\
\hline $\begin{array}{c}\text { Vaisman et al. } \\
{[20]}\end{array}$ & $\begin{array}{l}\text { Diabetic patients } \geq \\
18 \text { years old }(\mathrm{n}=25 ; \\
\text { intervention group } \\
=12 \text {, control group } \\
=13 \text { ) }\end{array}$ & $\begin{array}{l}\text { Yes (GTT ou } \\
\text { NGT) }\end{array}$ & $\begin{array}{c}\text { Intervention: } \\
\text { soy protein diet } \\
\text { compared to casein } \\
\text { formula }\end{array}$ & 12 weeks & $\begin{array}{l}\text { Plasma glucose levels, } \\
\text { postprandial glucose } \\
\text { levels, HbA1c, insulin, } \\
\text { plasma lipids, hsCRP, } \\
\text { albumin, prealbumin, } \\
\text { weight, blood pressure } \\
\text { and heart rate. }\end{array}$ & $\begin{array}{l}\text { Better response to } \\
\text { postprandial glycemic } \\
\text { control and decreased } \\
\text { HbA1c in the group that } \\
\text { used soy protein-based } \\
\text { diabetes-specific formula }\end{array}$ \\
\hline $\begin{array}{l}\text { García- } \\
\text { Talavera Espín } \\
\text { et al. [17] }\end{array}$ & $\begin{array}{l}\text { Hospitalized elderly } \\
\text { patients ( }=50 ; \\
\text { intervention group } \\
=24 \text {, control group } \\
=26 \text { ) }\end{array}$ & Yes (NGT) & $\begin{array}{c}\text { Intervention: } \\
\text { soy protein diet } \\
\text { compared to casein } \\
\text { formula }\end{array}$ & 6 months & $\begin{array}{l}\text { Nutritional status } \\
\text { (type and grade); } \\
\text { gastrointestinal } \\
\text { complications (diarrhea, } \\
\text { vomiting, constipation); } \\
\text { pressure injuries; } \\
\text { mortality }\end{array}$ & $\begin{array}{l}\text { Lower incidence of } \\
\text { diarrhea and vomiting, } \\
\text { fever and pressure } \\
\text { injury, higher percentage } \\
\text { of improved nutritional } \\
\text { status and lower } \\
\text { mortality in the group } \\
\text { that used soy protein } \\
\text { formula. }\end{array}$ \\
\hline Shao et al. [19] & $\begin{array}{l}\text { Adult and elderly } \\
\text { patients with acute } \\
\text { ischemic stroke }(\mathrm{n} \\
=104 ; \text { intervention } \\
\text { group = 53, control } \\
\text { group = 51) }\end{array}$ & Yes (NGT) & $\begin{array}{l}\text { Intervention: Soy } \\
\text { protein-based } \\
\text { diabetes-specific } \\
\text { enteral formula } \\
\text { compared to a } \\
\text { standard casein- } \\
\text { based formula }\end{array}$ & 12 months & $\begin{array}{l}\text { Effects of glycemic } \\
\text { response (fasting } \\
\text { glucose, postprandial } \\
\text { glucose, glucose } \\
\text { concentration, HOMAIR) }\end{array}$ & $\begin{array}{l}\text { Improved postprandial } \\
\text { glycemic control, insulin } \\
\text { resistance, beneficial } \\
\text { effects on HOMAIR and } \\
\text { fasting glucose, besides a } \\
\text { reduced CRP. }\end{array}$ \\
\hline
\end{tabular}




\section{Gastrointestinal Effects / Diet Tolerance}

The studies evaluating gastrointestinal effects demonstrated lower frequencies of vomiting, presence of gastric residuals, diarrhea, number of bowel movements and constipation in patients treated with soy protein source17,18. In the Viall et al. [18] study the groups received the same diet volume and the nitrogen balance was positive, without statistical difference. In addition, both were normocaloric and lactose free formulations with low residual content. The animal protein formula contained 38g of protein per liter approximately, $88 \%$ casein and $12 \%$ soybean, and the vegetable protein formula consisted of $50 \mathrm{~g}$ hydrolyzed soy protein per liter. The number of bowel movements, incidence of vomiting and large volumes of gastric residual content (except for individuals with jejunostomy - $9 \%$ of the sample) were higher in the group treated with casein formula with statistically significant difference ( $p$ $<0.05$ ), except for the incidence of diarrhea, which was higher in the group treated with casein formula, but it did not present statistical difference. In the García-Talavera Espín et al. [17] study both groups received similar diets, normocaloric (caloric density $1.0 \mathrm{kcal}$ $/ \mathrm{ml}$ ) and normoproteic (16\% of caloric value), which differed in protein source only. The group that received casein formula had more episodes of diarrhea ( $p<0.01)$, vomiting ( $p=0.05)$, fever $(p=$ 0.016 ) and also showed a higher incidence of constipation, without statistical difference. Therefore, the group that received soy formula had regular bowel movements more often. Besides that, the casein group had higher incidence of pressure injuries and mortality, but without statistical difference. In the study that evaluated the use of plant-based formula for glycemic control, the group that used soy as a protein source also had a lower frequency of infections that caused adverse effects, but without statistical significance. Also, there were no significant differences in the occurrence of vomiting and stool consistency between the two groups, but the frequency of bowel movements was lower in the soybean group ( $p=0.034$ ). Similar normocaloric diets (45\% carbohydrate, 38\% fat and $17 \%$ protein for soybean diet and 55\% carbohydrate, 30\% fat and 15\% protein for casein-based diet) were used in this study, and the participants received the same diet volume20. On the other hand, in the Shao et al. [19] study, no serious intolerance adverse events related to the formula were demonstrated during the study. There was no significant difference in the occurrence of flatulence or diarrhea, although the group that received the vegetable protein diet had lower occurrences, and no episodes of vomiting or acid reflux were reported.

\section{Nutritional Status}

The intervention group which, received soy protein in the García-Talavera Espín et al. [17] study, presented lower rates of malnutrition at hospital discharge (either mild, moderate or severe). Also, higher nutritional recovery rates, even without statistical difference, were observed. The soy protein group showed improvement in nutritional status in 8 cases and worsened in 2, while in the casein group there was improvement in 4 cases and worsening in 4 cases. The group that received soy protein had higher number of patients who returned to oral feeding at hospital discharge and a lower proportion of infections and antibiotic use. In the Viall et al. [18] and Vaisman et al. [20] studies, in which parameters of nutritional status were evaluated in a secondary way, no significant changes were observed in groups regarding weight, triceps skinfold and arm circumference19, and there was no significant difference in body mass index (BMI) values19 between groups.

\section{Metabolic Outcomes}

Biochemical parameters such as serum albumin, total lymphocyte count and total cholesterol were used in the GarcíaTalavera Espín et al. [17] study to assess nutritional status, demonstrating improvement in the parameters of the group that used soy protein source. In a study evaluating glycemic control in type 2 diabetic patients (T2D)20, patients receiving soy protein formula, characterized as diabetes-specific formula in the study group, had reduction in the glycated hemoglobin (HbA1c) levels and there were no significant differences in fasting blood glucose, fasting insulin, lipid parameters (triglycerides, total cholesterol, LDL and VLDL), albumin, prealbumin, C-reactive protein (CRP) and diastolic blood pressure when compared to the group receiving nutrition from animal protein source. However, the systolic blood pressure increased in the group that used casein as a protein source, while it decreased in the group that used soy. There were no differences among renal function biomarkers, creatinine and urea. In the Viall et al. [18] study, in which secondary biochemical parameters were evaluated, the same result was found: no significant change between groups in serum albumin, hemoglobin, creatinine, total lymphocyte count, alkaline phosphatase, gamma glutamyl transferase, or bilirubin values was observed during the study. The study that compared protein sources in post stroke patients [19], showed that the use of soy protein formula improved postprandial glycemic control, and postprandial capillary glucose, mean glucose and peak glucose levels after treatment were significantly lower compared to their baselines, and no significant postprandial glucose changes were observed in the patients of the group that used the casein formula after treatment [20]. Also, the fasting glucose was significantly lower with soy formula and showed no difference with the casein formula. The HOMAIR index (Homeostasis Model Assessment of Insulin Resistance) did not differ significantly between the two groups. However, the soy protein resulted in a decrease in HOMAIR, whereas no significant changes were found within the casein group. The HOMAIR index estimates the insulin resistance based on the relationship between fasting glucose and insulin levels, with higher HOMA-IR values representing a more severe insulin resistance (IR). It is an efficient 
method to assess insulin resistance, widely used for primary prevention and diagnosis of diabetes [21]. No significant difference was found in the incidence of hypoglycemic episodes.

\section{Discussion}

Based on the database searches, this is the first review to evaluate the effects of vegetable protein as a protein source of enteral formulas when compared to animal protein sources. Few studies have proposed to analyze the use of plant source protein when compared to animal source protein in enteral formulas. It was observed that the use of vegetable protein formulas resulted in lower incidence of gastrointestinal complications such as vomiting, diarrhea and excess gastric residuals, improved nutritional status and better glycemic control in the patients studied when compared to the groups that used animal protein source formulas. Enteral nutrition is a technique used in patients at nutritional risk who cannot eat sufficiently through oral route [22]. Enteral formulas should contain all the nutrients needed for a complete nutrition. When comparing the use of formulas with different protein sources, it is observed that the vegetable protein had greater efficacy. Regarding protein quality assessment, there are several methods. Among them the Protein Digestibility Corrected Amino Acid Score (PDCAAS) and the Digestible Indispensable Amino Acid Score (DIAAS) are the two main methods for determining protein integrity by its unique concentration and digestibility of essential amino acids [23]. The PDCAAS is a chemical method introduced by FAO / WHO in 1989 to assess protein quality and it was adopted by the US Food and Drug Administration (FDA) in 1993. The PDCAAS values are determined by the ratio of the limiting amino acid concentration in the protein to be evaluated and the concentration of the same amino acid in a reference or standard protein. This ratio is then adjusted for the true protein digestibility, which represents the difference between the amount of nitrogen ingested and the excreted fecal nitrogen, which is responsible for metabolic losses [24].

However, this method does not count the excreted fecal nitrogen that is produced from the fermentation of gut bacteria, and the true fecal digestibility that is being used to calculate the PDCAAS score does not cover the whole table in terms of total digestibility[25]. This way, FAO recommended replacing the PDCAAS protein quality assessment method by DIASS [26]. The DIASS has been proposed to address the limitations of PDCAAS, the main one is that DIASS uses ileal digestibility coefficients for each amino acid instead of using true fecal nitrogen digestibility [27]. The DIAAS can provide comprehensive information on protein quality in foods [28]. Studies show that quality, rather than total protein quantity, may be more important from the point of view of human health and well-being [23-27]. In this review it was demonstrated that formulas with vegetable protein source, being soy the protein source used in all studies, presented similar or superior effects when compared with formulas with animal protein source, which could be demonstrated by García-Talavera Espín et al. [17] in their study, in which patients who received formula with vegetable protein source had higher prevalence of nutritional recovery. Also, to understand the relationship between muscle mass and food intake, in the study conducted with 168 elderly people with T2D was evaluated the relationship between muscle mass, through the skeletal muscle index, and the type of protein ingested and it was found that the vegetable protein intake was positively associated with increased muscle mass in elderly [28], corroborating with the study mentioned previously. The adequate intake of a variety of plant-based protein sources and necessary calories is easily achieved $[29,30]$, and the protein requirements can be easily met even in elderly, pregnant women / infants and children31.

The soy protein has a good amino acid profile and can be considered as the main source of protein due to its protein quality, covering the nutritional needs $[32,33]$. The soy protein aminogram is very similar to casein, a protein source commonly used in enteral formulas [34], which corroborates the findings of this review, where soy protein showed similar or superior results. The whey protein has higher amounts of some essential amino acids, however, there have been no reported differences in muscle protein synthesis and other outcomes for its use when compared to soy protein 12 . In general, vegetable protein sources contain limited amounts of one or more essential amino acids. However, it is now recognized that, when consumed a varied of vegetable foods daily, the strict combination of proteins in the same meal is not required [30-35]. This way, in an enteral formula, all essential amino acids would be contemplated once they aim to meet the total needs of individuals. According to a meta-analysis review study, vegetable protein incorporation is no different from animal protein in the human organism [36] and, when combined to supply all essential amino acids, vegetable proteins provide an excellent source of proteins10. when analyzing the metabolic outcomes, it was observed that soy protein formulas provided better glycemic control. The soy protein was an important factor that contributed to reduce insulin resistance and fasting glucose demonstrating to be more effective in improving insulin sensitivity and fasting glucose concentrations in patients with T2D and metabolic syndrome than another protein source $[37,38]$. A possible hypothesis would be that soy protein presented better stimulation of $\beta$-cell proliferation and stimulation, and insulin secretion [39].

Vegetable protein sources, such as soybeans, legumes and oilseeds, individually have advantages of lipid reduction by their specific components (specific protein fractions, viscous fibers, polyunsaturated fatty acids and plant sterols). The substitution of animal protein source by a vegetable protein source also has advantages by displacing saturated fatty acids. Systematic reviews 
and meta-analyzes of randomized controlled trials demonstrate significant lipid reductions by combining plant protein sources [4043], which could be verified by the metabolic effects analyzed in the studies of this review. Regarding gastrointestinal complications, it was observed that the formulas with vegetable protein had lower prevalence. Gastrointestinal effects and complications related to enteral nutrition therapy, such as reduced gastric emptying time, vomiting and diarrhea, for example, hinder proper nutrition and may impair the patient's nutritional status17-19. Vegetable protein source formulas have been shown to be well tolerated and effective. The study of van den Braak et al. [44] evaluated the coagulation behavior of protein solutions and demonstrated that calcium caseinate and sodium caseinate produced a total wet coagulation of $43.5 \pm 0.7 \mathrm{~g}$ and $52.7 \pm 6.2 \mathrm{~g}$, respectively, while whey protein, soybean and pea produced no measurable clotting, demonstrating better gastric behavior of vegetable proteins when compared to those commonly used in standard formulas such as those used in the casein studies. In the preparation of two formulated powders for use in soybean-based enteral nutrition, their protein quality was evaluated, and it was verified that both formulated presented good fluidity and stability, besides protein quotient and digestibility similar to the control (casein). Thus, considering the findings in the studies, the use of soy-based formulas in enteral formulas has shown beneficial effects on clinical outcomes of patients and treatment of diseases. Besides that, these formulas have high nutritional value, good tolerance and low cost [45].

One of the limitations of this study is that it analyzed only the protein source of the formulas and not the total nutrient content. Regardless the method to be used for protein quality assessment, protein quality methods that consider only the content and distribution of essential amino acids can be misleading because they represent the biological value of a single nutrient alone, not the total effects of consumption the source of this nutrient as a whole27. This review focused on proteins, as they are the subject of great debate due to their protein quality. The source of the nutrients that are part of the formula is an important aspect to be taken into consideration due to the number of individuals with restrictions, such as food allergies and intolerances, or the increased number of vegetarians, especially strict vegetarians/vegans. Interest and adherence to vegetarianism has been growing [46,47]. According to a 2016 survey, approximately $3.3 \%$ of American adults are vegetarians and about $46 \%$ of these are vegans [48]. There are many reasons that lead individuals to adopt a vegetarian diet, and, in this case, vegan patients on enteral nutrition therapy would need a formula made up of an exclusively vegetarian protein source. Despite the limited number of studies that served as the basis for this review, this study stands out for its originality and scarcity of the subject in the literature, in addition to provide support for health professionals to prescribe safely.

\section{Conclusion}

The use of soy protein enteral formulas seems to be efficient to improve nutritional status and glycemic control in diabetics, as well as a lower incidence of gastrointestinal complications in individuals fed by enteral nutrition. Due to the scarcity of studies comparing protein sources in the outcomes of different clinical situations, there is the necessity to expand studies with this theme in order to elucidate the role and functions of plant proteins in the metabolism. In addition, there are no adequate formulas available on the market to meet the requirements of physiological changes and lifestyle choices.

\section{References}

1. Taylor B, McClave S, Martindale R, Warren M, Johnson D, et al. (2016) Guidelines for the Provision and Assessment of Nutrition Support Therapy in the Adult Critically Ill Patient: Society of Critical Care Medicine (SCCM) and American Society for Parenteral and Enteral Nutrition (A.S.P.E.N.). Crit Care Med. 44(2): 390-438.

2. Ueno E, Koffke M, Voigt VR (2018) Perfil de pacientes hospitalizados em uso de terapia enteral. BRASPEN J 33(2): 194-198.

3. Singer P, Blaser AR, Berger MM, Alhazzani W, Calder PC, et al. (2019) ESPEN guideline on clinical nutrition in the intensive care unit. Clin Nutr 38(1): 48-79.

4. Doig GS, Heighes PT, Simpson F, Sweetman EA, Davies AR (2009) Early enteral nutrition provided within 24 hours of injury or intensive care unit admission significantly reduces mortality in critically ill patients: a meta-analysis of randomised controlled trials. Intensive Care Med 35: 2018-27.

5. van Blarcom A, McCoy MA (2018) New Nutrition Guidelines: Promoting Enteral Nutrition via a Nutrition Bundle. Crit Care Nurse 38(3): 46-52.

6. Rasmussen NML, Belqaid K, Lugnet K, Nielsen AL, Rasmussen HH, Beck AM (2018) Effectiveness of multidisciplinary nutritional support in older hospitalised patients: A systematic review and meta-analyses. Clin Nutr ESPEN 27: 44-52.

7. Preiser JC, van Zanten AR, Berger MM, Biolo G, Casaer MP, et al. (2015) Metabolic and nutritional support of critically ill patients: consensus and controversies. Crit Care 19:35.

8. Puthucheary ZA, Rawal J, McPhail M, Connolly B, Ratnayake G, et al. (2013) Acute skeletal muscle wasting in critical illness. JAMA 310: 1591600.

9. Rand WM, Pellett PL, Young VR (2003) Meta-analysis of nitrogen balance studies for estimating protein requirements in healthy adults. Am J Clin Nutr 77(1): 109-1027.

10. Hoffman JR, Falvo MJ (2004) Protein - Whichis Best? J Sports Sci Med 3(3): 118-130.

11. Joy JM, Lowery RP, Wilson JM, Purpura M, De Souza EO, et al. (2003) The effects of 8 weeks of whey or rice protein supplementation on body composition and exercise performance. Nutr J 12: pp.86.

12. Messina M, Lynch H, Dickinson JM, Reed KE (2018) No Difference Between the Effects of Supplementing with Soy Protein Versus Animal Protein on Gains in Muscle Mass and Strength in Response to Resistance Exercise. Int J Sport Nutr Exerc Metab 28(6): 674-685.

13. Mathieu S, Dorard G (2016) Vegetarianism and veganism lifestyle: Motivation and psychological dimensions associated with selective diet. Presse Med 45(9): 726-733. 
14. Ruby MB, Heine SJ, Kamble S, Cheng TK, Waddar M (2013) Compassion and contamination. Cultural differences in vegetarianism. Appetite. 71 340-348.

15. Leitzmann C (2014) Vegetarian nutrition: past, present, future. Am J Clin Nutr 100(1): 496S-502S.

16. Archifontaine CP, Trindade MA (2019) Bioética, saúde e realidade brasileira. Rev Bioét 27(1): 439-445.

17. García-TalaveraEspín NV, Gómez Sánchez MB, ZomeñoRos AI, Nicolás Hernández M, González Valverde FM, et al. (2010) Comparative study of two enteral feeding formulas in hospitalized elders: casein versus soybean protein. Nutr Hosp 25(4): 606-612.

18. Viall C, Porcelli K, Teran JC, Varma RN, Steffee WP, et al. (1990) A doubleblind clinical trial comparing the gastrointestinal side effects of two enteral feeding formulas. J Parenter Enteral Nutr 14(3): 265-269.

19. Shao Y, Heng W, Li S, Xu Y, Hu G, et al. (2018) Tube feeding with a diabetes-specific enteral formula improves glycemic control in severe acute ischemic stroke patients. J Parenter Enteral Nutr 42(5): 926-32.

20. Vaisman N, Lansink M, Rouws CH, van Laere KM, Segal R, et al. (2009) Tube feeding with a diabetes-specific feed for 12 weeks improves glycaemic control in type 2 diabetes patients. Clin Nutr 28(5): 549-555.

21. Tang Q Li X, Song P, Xu L (201) Optimal cut-off values for the homeostasis model assessment of insulin resistance (HOMA-IR) and pre-diabetes screening: Developments in research and prospects for the future. Drug Discov Ther 9(6): 380-385

22. Galán MG, Drago SR (2014) Effects of Soy Protein and Calcium Levels on Mineral Bio accessibility and Protein Digestibility from Enteral Formulas. Plant Foods Hum Nutr 69(3): 283-289.

23. Huang S, Wang LM, SivendiranT, Bohrer BM (2017) Review: Amino acid concentration of high protein food products and an overview of the current methods used to determine protein quality. Crit Rev Food Sci Nutr 58(15): 2673-2678.

24. World Health Organization (1989) Protein quality evaluation: Report of the Joint FAO/WHO Expert Consultation, Bethesda, MD, USA 4-8 December 1989. Rome (Italy): FAO; 1991.

25. Schaafsma G (2012) Advantages and limitations of the protein digestibility-corrected amino acid score (PDCAAS) as a method for evaluating protein quality in human diets. Br J Nutr 108: S333-S336.

26. FAO (2013) Report on dietary protein quality evaluation in human nutrition, paper no. 92: Food and Agriculture Organization of the United Nations. Rome: FAO; 2013.

27. Katz DL, Doughty KN, Geagan K, Jenkins DA,Gardner CD (2019) Perspective: The Public Health Case for Modernizing the Definition of Protein Quality. Adv Nutr 10(5): 755-764.

28. Miki A, Hashimoto Y, Matsumoto S, Ushigome E, Fukuda T, et al. (2017) Especially Vegetable Protein Intake, Is Associated with Higher Skeletal Muscle Mass in Elderly Patients with Type 2 Diabetes. J Diabetes Res pp: 7985728.

29. Schmidt JA, Rinaldi S, Ferrari P, Carayol M, Achaintre D, et al. (2015) Metabolic profiles of male meat eaters, fish eaters, vegetarians, and vegans from the EPIC-Oxford cohort 2015. Am J Clin Nutr 102(6):15181526.

30. Burkholder N, Rajaram S, Sabaté J (2016) Vegetarian Diets. Encyclopedia of Food and Health.

31. Agnoli C, Baroni L, Bertini I, Ciappellano S, Fabbri A, et al. (2017) Position paper on vegetarian diets from the working group of the Italian Society of Human Nutrition. Nutr Metab Cardiovasc Dis. 27(12):1037-1052.
32. Young VR, Wayler A, Garza C, Steinke FH, Murray E, et al. (1984) A longterm metabolic balance study in young men to assess the nutritional quality of an isolated soy protein and beef proteins. Am J Clin Nutr 39(1): 8-15.

33. Young VR (1991) Soyprotein in relation to human protein and aminoacid nutrition. J Am Diet Assoc 91(7): 828-835.

34. Gorissen SHM, Crombag JJR, Senden JMG, Waterval WAH, Bierau J, et al. (2018) Protein content and amino acid composition of commercially available plant-based protein isolates. Amino Acids 50(12): 1685-1695.

35. Barr, SI (2015) Vegetarian diets. World Rev Nut Diet 111: 53-57.

36. Rand WM, Pellett PL, Young VR (2003) Meta-analysis of nitrogen balance studies for estimating protein requirements in healthy adults. Am J Clin Nutr 77(1):109-1027

37. Azadbakht L, Atabak S, Esmaillzadeh A (2008) Soy protein intake, cardiorrenal indices, and C-reactive protein in type 2 diabetes with nephropathy: a longitudinal randomized clinical trial. Diabetes Care 31(4):648-54.

38. Zhang XM, Zhang YB, Chi MH (2016) Soy protein supplementation reduces clinical indices in type 2 diabetes and metabolic syndrome. Yonsei Med J 57(3): 681-689.

39. Gilbert ER, Liu D (2013) Anti-diabetic functions of soy isoflavone genistein: mechanisms underlying its effects on pancreatic $\beta$-cell function. Food Funct 4(2): 200-2012.

40. Jenkins DJ, Mirrahimi A, Srichaikul K, Berryman CE, Wang L, et al (2010) Soy protein reduces serum cholesterol by both intrinsic and food displacement mechanisms. J Nutr 140: 2302s-2311s.

41. Sabaté J, Oda K, Ros E (2010) Nut consumption and blood lipid levels: a pooled analysis of 25 intervention trials. Arch Intern Med 170(9): 821827.

42. Blanco Mejia S, Kendall CWC, Viguiliouk E, Augustin LS, Ha V, et al. (2014) Effect of tree nuts on metabolic syndrome criteria: a systematic review and meta-analysis of randomised controlled trials. BMJ Open 4(7): e004660.

43. Ha V, Sievenpiper JL, de Souza RJ, Jayalath VH, Mirrahimi A, et al. (2014) Effect of dietary pulse intake on established therapeutic lipid targets for cardiovascular risk reduction: a systematic review and meta-analysis of randomized controlled trials. CMAJ 186(8): E252-E262.

44. van den Braak CC, Klebach M, Abrahamse E, Minor M, Hofman Z, Knol $\mathrm{J}$, et al. (2013) A novel protein mixture containing vegetable proteins renders enteral nutrition products non-coagulating after in vitro gastric digestion. Clin Nutr 32(5): 765-771.

45. Monteiro JBR, Costa NMB,Esteves EA, Milagres KH (2004) Avaliação da qualidade protéica de dois formulados em pó, à base de soja enriquecidos com zinco, selênio e magnésio para utilização em nutrição enteral. Ciênc. Tecnol. Aliment 24(1): 006-010.

46. Larson CL, Johansson GK (2002) Dietary intake and nutritional status of young vegans and omnivores in Sweden. Am J Clin Nutr 76(1):100-106.

47. Couceiro P, Slywitch E, Lenz F (2008)Padrão alimentar da dieta vegetariana. Einstein 6(3): 365-373.

48. Melina V, Craig W, Levin S (2016) Position of the Academy of Nutrition and Dietetics: Vegetarian Diets. J Acad Nutr Diet 116(12): 1970-1980. 
(C) (P) This work is licensed under Creative

To Submit Your Article Click Here: Submit Article

DOI: $10.32474 /$ RRHOAJ.2020.05.000221

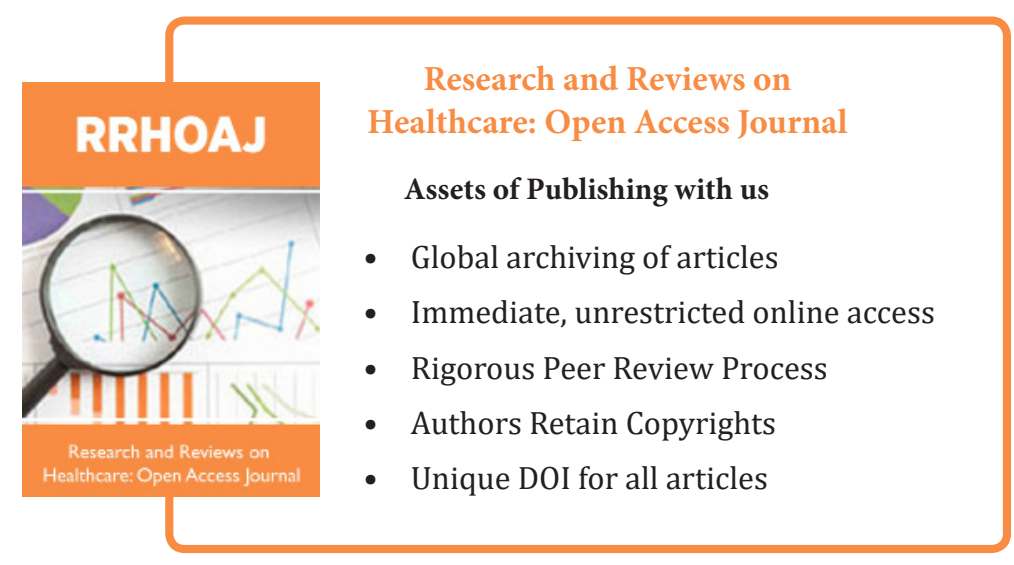

